\title{
Alteration of certain acaricides toxicity owing to mixing with fertilizers
}

\author{
M. M. Y. El-Shazly \\ Plant Protection Dept., Fac. of Agric. (Saba Basha), Alexandria Univ., Egypt
}

\begin{abstract}
The lethal effect of five acaricides alone or mixed individually with ten separate fertilizers, on the phytophagus mite Tetranychus urticae, was evaluated after 72 hours under laboratory conditions of $30^{\circ} \mathrm{C} \pm 5$ and $\mathrm{R}$. H. $70 \% \pm 5$. The tested acaricides were fenpyroximate (Ortus ${ }^{\circledR} 5 \%$ EC), ethion (Endo ${ }^{\circledR} 50 \%$ EC), abamectin (Vertimec ${ }^{\circledR} 1.8 \%$ EC), chlorfenapyr (Challenger ${ }^{\circledR}$ 36\% SC) and hexythiazox (Maccomite ${ }^{\circledR} 10 \%$ WP). Used fertilizers were potassium sulphate, ferrous sulphate hepta hydrate, magnesium sulphate hepta hydrate, zinc sulphate hepta hydrate, ammonium sulphate, ammonium nitrate, calcium nitrate, di ammonium phosphate, phosphoric acid and urea. $\mathrm{LC}_{95}$ values of the previous acaricides singly were $422.8,2112.9,6,0.9$ and 363.6 p.p.m., respectively. $\mathrm{LC}_{50}$ values of the previous acaricides singly were: $329.8,1851$, 5.5, 0.4 and 259.6 p.p.m., respectively. The recommended doses of the previous acaricides were $1.5,0.8,72.8,1007.6$ and 0.8 fold of $\mathrm{LC}_{50}$ values of these acaricides, respectively. Potassium sulphate had a synergistic effect on each of Ortus ${ }^{\circledR}$ and Vertimec ${ }^{\circledR}$, but had an antagonistic effect on Endo ${ }^{\circledR}$, Challenger ${ }^{\circledR}$ and Maccomite ${ }^{\circledR}$. Each of ferrous sulphate hepta hydrate, magnesium sulphate hepta hydrate, zinc sulphate hepta hydrate, ammonium sulphate, ammonium nitrate, calcium nitrate and di ammonium phosphate had an antagonistic effect on all the examined acaricides. Phosphoric acid had a synergistic effect on Ortus ${ }^{\circledR}$ only but had an antagonistic effect on the rest tested acaricides, Urea had a synergistic effect on Ortus ${ }^{\circledR}$ and Challenger ${ }^{\circledR}$ but had an antagonistic effect on the rest acaricides.
\end{abstract}

Key words: Tetranychus urticae, acaricides, fertilizers, mixing, toxicity.

\section{INTRODUCTION}

The extensive use of synthetic chemicals for pest control is recognized as a major threat to ecosystem integrity. There have been many studies of agrochemical reduction technologies, but little work to date has been done to achieve a combined reduction of chemical pesticides and chemical fertilizers (Wan et al., 2013). Contamination by nitrates and pesticides in rural regions as the main element of agricultural diffuse pollution has been gradually realized by agricultural and environmental scientists (Li and Zhang, 1999). Although Heindel et al. (1994) mentioned that pesticides and fertilizers, as used in modern agriculture, contribute to the overall low-level contamination of groundwater sources, they found that one mixture containing aldicarb, atrazine, dibromochloropropane, 1,2dichloropropane, ethylene dibromide, and simazine plus the fertilizer ammonium nitrate at levels up to 100 -fold greater than the median concentrations in groundwater supplies in California or Iowa did not cause any detectable reproductive (mice), general, or developmental toxicity (rats).

Synergistic effect of fertilizers on pesticides was proved by Chahal et al. (2012) who found that sprays of fungicides in combination with micronutrients were more effective in preventing canopy defoliation caused by early and late leaf spot disease than single fungicide spray.

The two-spotted spider mite, T. urticae, is one of the most destructive pests of various orchard trees and gardens, Kwon et al. (2010). It is one of the economically most important pests in a wide range of outdoor and protected crops worldwide. Its control has become problematic in many areas worldwide and largely based on the use of insecticides and acaricides, Leeuwena et al. (2010). Ahmad et al. (2009) showed that the total effects of fenpyroximate and abamectin were found harmful to the predatory mites at the highest field recommended concentrations. Hence, the present study displays a comparative toxicity of the five acaricides.

Mixing foliar nutrients with acaricides is a usual practice aiming to reduce effort, time and costs of spraying. Therefore, the present study determines the fertilizers that reduce the acaricides efficiency (incompatibility) to avoid its mixing. On the other hand, it determines the fertilizers that activate the acaricides (compatibility) aiming to reduce the doses of the acaricides that affect useful organisms, human, and environment.

\section{MATERIALS AND METHODS}

\section{Residual film bioassay:}

The lethal effect of some commercially available acaricides; Ortus ${ }^{\circledR} \quad 5 \%$ EC, Endo ${ }^{\circledR} \quad 50 \%$ EC, Vertimec $^{\circledR} 1.8 \%$ EC, Challenger ${ }^{\circledR} 36 \%$ SC and Maccomite $^{\circledR} 10 \%$ WP singly or in a mixture containing 1:1 (v/v) of one acaricide and a 5000 p.p.m. solution of one of the fertilizers; potassium sulphate, ferrous sulphate hepta hydrate, magnesium sulphate hepta hydrate, zinc sulphate hepta hydrate, ammonium sulphate, ammonium nitrate, calcium nitrate, di ammonium phosphate, phosphoric acid, and urea, on the phytophagous mite $T$. urticae, was 
examined under laboratory conditions $\left(30^{\circ} \mathrm{C} \pm 5\right.$ and R. H. $70 \% \pm 5$ ).

Distilled water was used to prepare different diluted concentrates of each acaricide. Likewise, a 10000 p.p.m. solution of each fertilizer was prepared. Three fresh leaves of water melon plants were dipped in each examined diluted acaricide. Similarly, three leaves were dipped in a mixture that contains $1: 1(\mathrm{v} / \mathrm{v})$ of a diluted acaricide and a 5000 p.p.m. fertilizer solution. The leaves were left for an hour to dry. The petioles of the treated leaves were put in very small bottles filled with distilled water to keep the leaves alive for a long time while, the other terminates were surrounded with a mixture of vaseline and camphor oil to avoid escaping of the examined mites. Ten live adult mites were transferred very gently from fresh leaves of water melon plants to the treated leaves by using a fine camel hair brush. For control, similar steps were done with leaves of water melon plants treated with distilled water. The number of dead mites were counted and recorded after 72 hours of the treatments.

\section{Statistical analysis:}

Concentrations of each acaricide or acaricide / fertilizer mixture that caused response percentages between $0 \%$ and $100 \%$, were considered for creating the regression equations $(\mathrm{Y}=\mathrm{a}+\mathrm{bx}) . \mathrm{LC}_{95}$ values (lethal concentration for $95 \%$ of the population), $\mathrm{LC}_{50}$ values (median lethal concentration) and slope were calculated as described by Finney (1971). Toxicity index (TI) and the relative toxicity (RT) of each tested acaricide were also calculated according to Sun (1950). The ratios between the recommended doses of the five acaricides in relation to their $\mathrm{LC}_{50}$ values were calculated. Antigonistic or synergistic effects of the fertilizers were calculated as the following eqiuation:

Antagonistic or synergistic ratio of a fertilizer (S.R.) = [ $\mathrm{Lc}_{50}$ value of the acaricide/( $\mathrm{L} \mathrm{c}_{50}$ value of the acaricide / fertilizer mixture)]

\section{RESULTS AND DISCUSSION}

\section{Toxicity parameters of the five acaricides:}

$\mathrm{LC}_{95}$ (p.p.m.), $\mathrm{LC}_{50}$ (p.p.m.), T.I., R.T. values and the recommended doses of the five acaricides are shown in Table (1). The ratios between the recommended doses of the five acaricides in relation to their $\mathrm{LC}_{50}$ values are shown as well. $\mathrm{LC}_{50}$ values of the five acaricides are graphically illustrated in Figure (1).

Also, the relative toxicity (RT) was calculated considering the least toxic acaricide (Endo ${ }^{\circledR} 50 \%$ EC) having a figure of toxicity equal to 1.00 . Therefore, the toxicity of the tested acaricides can be arranged in an ascending order as follows: Ortus ${ }^{\circledR} 5 \% \mathrm{EC}$ which showed higher toxicity than Endo $^{\circledR} 50 \%$ EC by 5.61 fold, Maccomite $^{\circledR} \quad 10 \%$ WP (RT=7.13 fold), Vertimec $^{\circledR} 1.8 \%$ EC (RT $=336.79$ fold) and the most toxic acaricide; Challenger ${ }^{\circledR} 36 \%$ SC (RT $=4654.26$ fold).

Good comparative toxicity of Abamectin agrees with the results of Koch et al. (2009) who found that resistance ratios of $T$. urticae to Abamectin were low in all populations collected from ten Korean commercial apple orchards. Also, good comparative toxicity of Maccomite agrees with the results of Gough (1990) who found that hexythiazox (Maccomite 10\% WP) gave excellent control against the populations of the two-spotted spider mite (Tetranychus urticae Koch), not previously exposed to acaricides, but was completely ineffective, due to resistance, at one site where Clofentezine had been applied repeatedly for 2 years before the trial. Palevsky et al. (2004) found that applying a single treatment with the acaricides Hexythiazox or Abamectin when the first mites were found on the fruit provided seasonal pest control.

\section{Effect of the fertilizers on the toxicity of the acaricides.}

2.1. Toxicity parameters of the acaricide / fertilizer mixtures.

$\mathrm{LC}_{95}$ and $\mathrm{LC}_{50}$ values (p.p.m.) of the evaluated acaricides combined with different fertilizers and tested against the red spider mite $T$. urticae under laboratory conditions $\left(30^{\circ} \mathrm{C} \pm 5\right.$ AND R. H $70 \% \pm 5$ ) are shown in Table (2). $\mathrm{LC}_{50}$ values are graphically illustrated in Figures (2-6).

\subsection{The joint action of the fertilizers and the acaricides.}

Antagonistic or synergistic effects of the fertilizers were calculated, displayed in table (3) and graphically illustrated in figures (7-16). Ratios $>1$ mean that the fertilizer has a synergistic effect on the acaricide. Ratios $<1$ mean that the fertilizer has an antagonistic effect on the acaricide.

Most fertilizers showed an antagonistic effect on the evaluated acaricides despite certain previous studies illustrated that fertilizers singly show lethal effect on mites. Cao et al. (2011) found that chemical fertilizer treatments reduced the abundance and diversity of soil mites after a continuous 11-year field experiment. Also, Lu et al. (1995) found that Urea $(0.6 \%)+\mathrm{K} \mathrm{H} 2 \mathrm{PO} 4(0.4 \%)+\mathrm{K} 2 \mathrm{SO} 4(0.3 \%)+$ the surface-active agent KODK $(0.03 \%)$ was the best combinations for citrus red mite control, giving better results than the acaricides. In addition, Veverka and Oliberius (1986) showed that an equimolar mixture of ammonium nitrate and urea was toxic to T. urticae. When Oliberius and Veverka (1985) studied the insecticidal and acaricidal activity of various nitrogen 


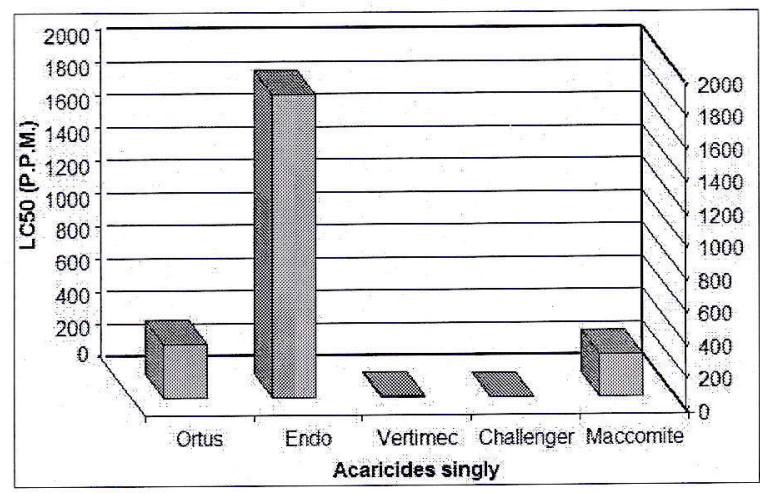

Fig. (1): $\operatorname{Lc}_{50}$ values of different acaricides.

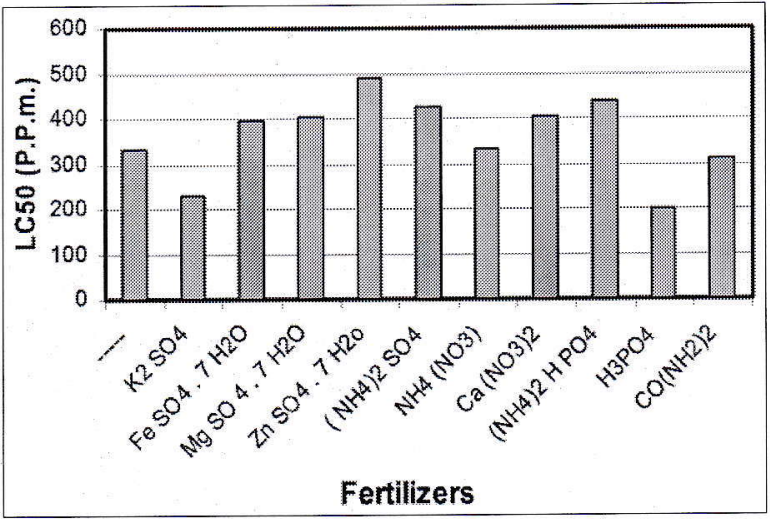

Fig. (2): $\mathrm{LC}_{50}$ values of Ortus mixed with different fertilizers, against $T$. urticae.

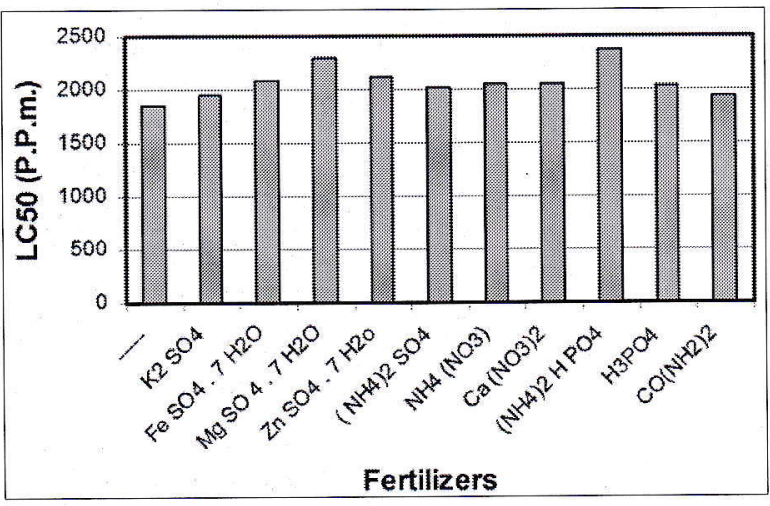

Fig. (3): $\mathrm{LC}_{50}$ values of Endo mixed with different fertilizers, against $T$. urticae.

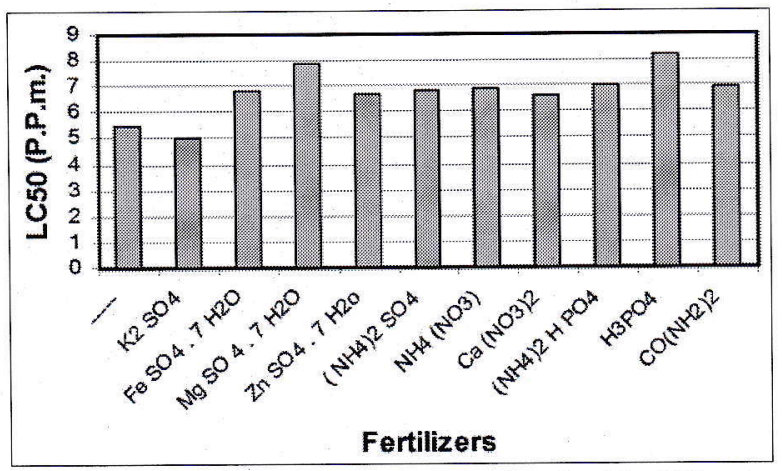

Fig.(4): $\mathrm{LC}_{50}$ values of Vertimec mixed with different fertilizers, against $T$. urticae.

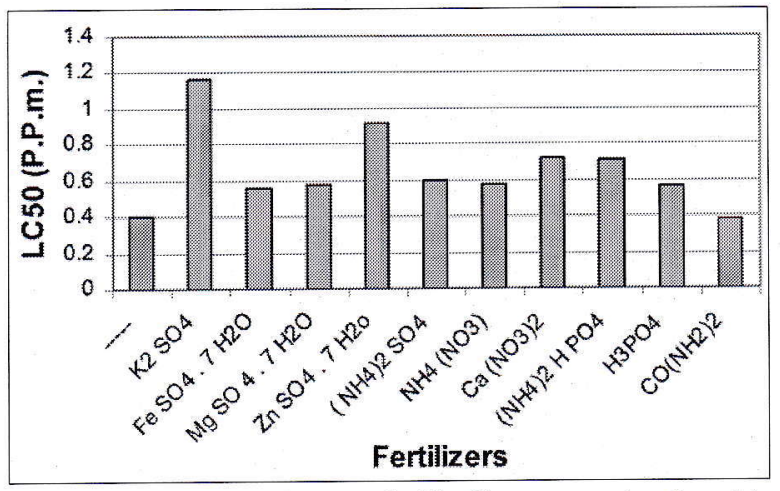

Fig. (5): $\mathrm{LC}_{50}$ values of Challenger mixed with different fertilizers, against $T$. urticae.

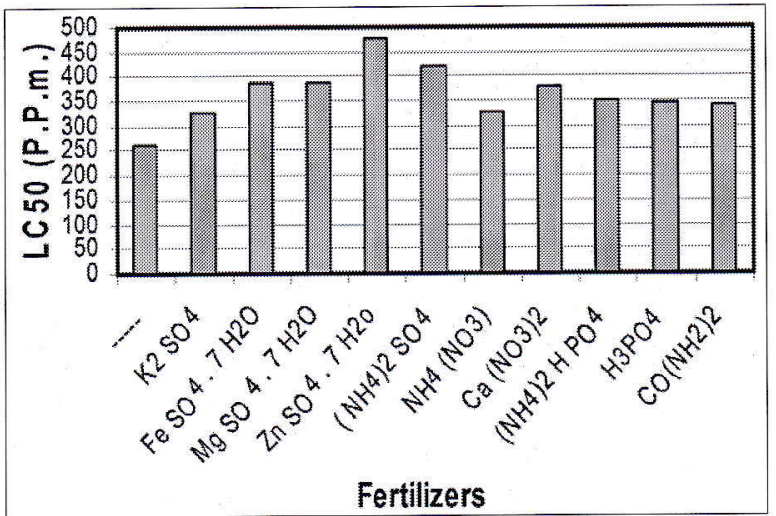

Fig. (6): $\mathrm{Lc}_{50}$ values of Maccomite mixed with different fertilizers, against $T$. urticae.

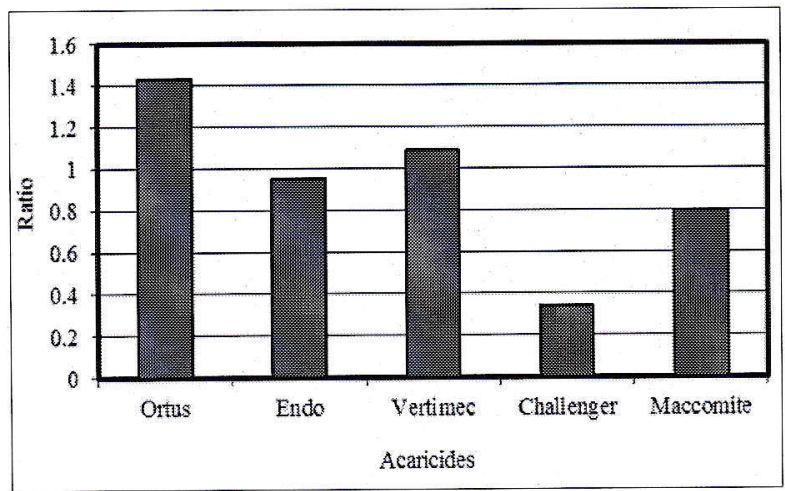

Fig. (7): Joint action of $\mathrm{K}_{2} \mathrm{SO}_{4}$ with different acaricides against $T$. urticae.

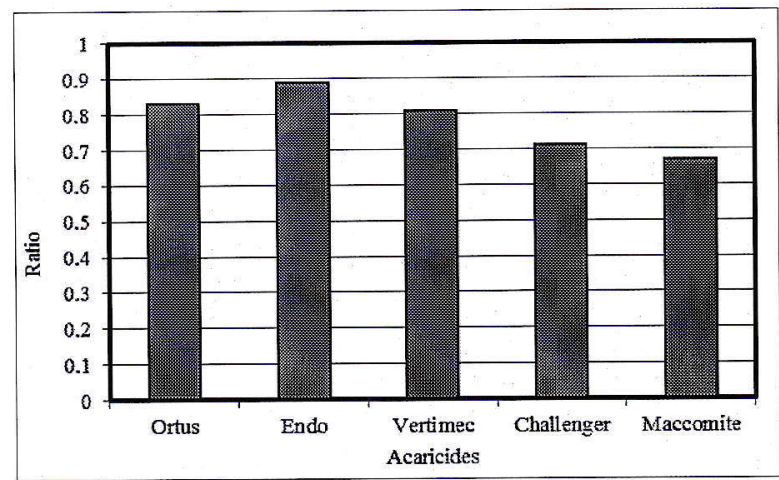

Fig. (8): Joint action of $\mathrm{FeSO}_{4}$. $7 \mathrm{H}_{2} \mathrm{O}$ with different acaricides against $T$. urticae. 


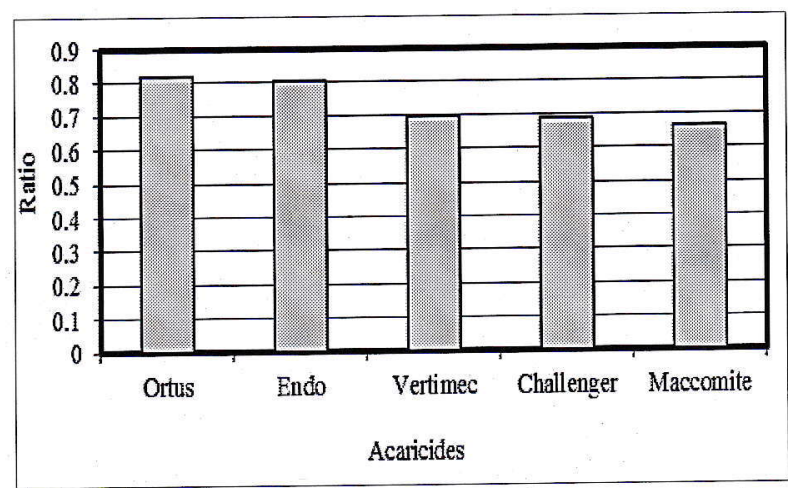

Fig.(9): Joint action of $\mathrm{MgSO}_{4} \cdot 7 \mathrm{H}_{2} \mathrm{O}$ with different acaricides against $T$. articae.

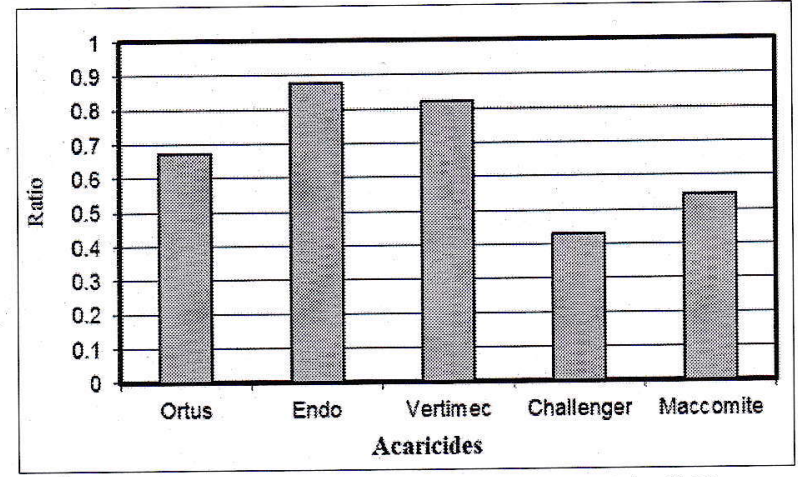

Fig. (10): Joint action of $\mathrm{Zn} \mathrm{SO}_{4} .7 \mathrm{H}_{2} \mathrm{O}$ with different acaricides against $T$. articae.

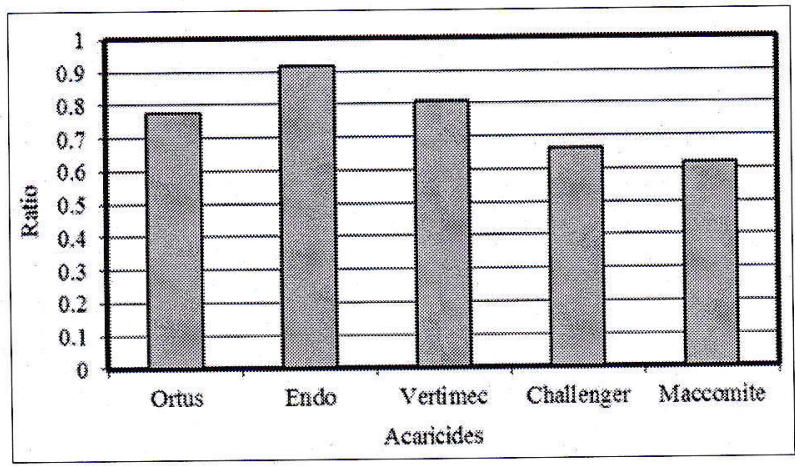

Fig. (11): Joint action of $\left(\mathrm{NH}_{4}\right)_{2} \mathrm{SO}_{4}$ with different acaricides against $T$. urticae.

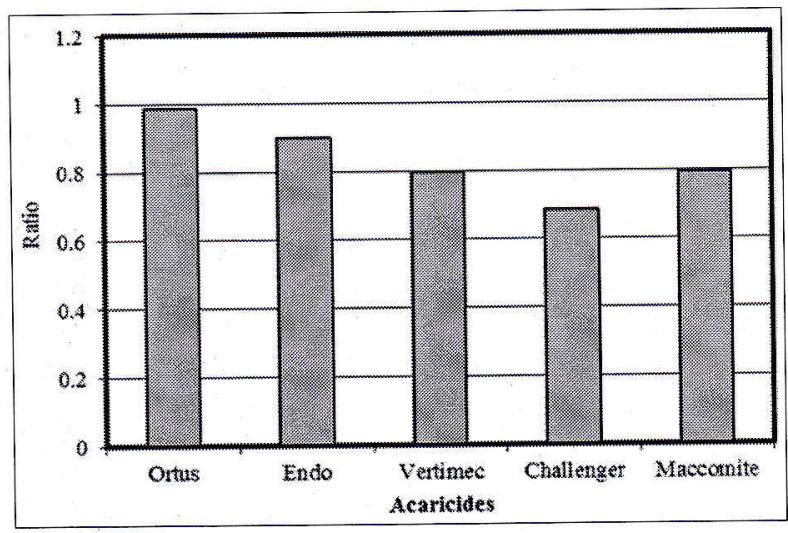

Fig. (12): Joint action of $\mathrm{NH}_{4}\left(\mathrm{NO}_{3}\right)$ with different acaricides against $T$. urticae.

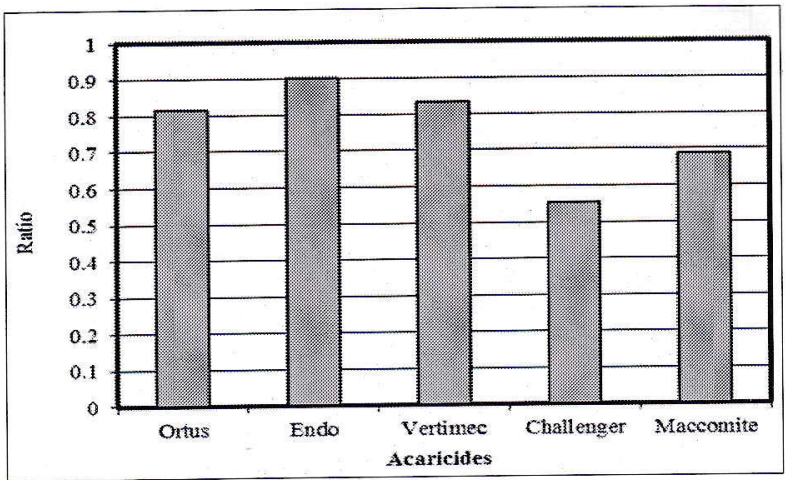

Fig. (13): Joint action of $\mathrm{Ca}\left(\mathrm{NO}_{3}\right)$ with different acaricides against $T$. urticae.

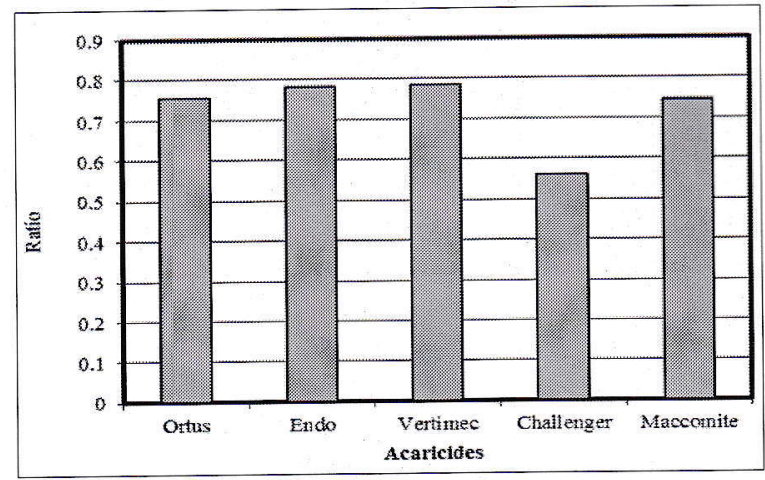

Fig. (14): Joint action of $\left(\mathrm{NH}_{4}\right)_{2} \mathrm{HPO}_{4}$ with different acaricides against $T$. urticae.

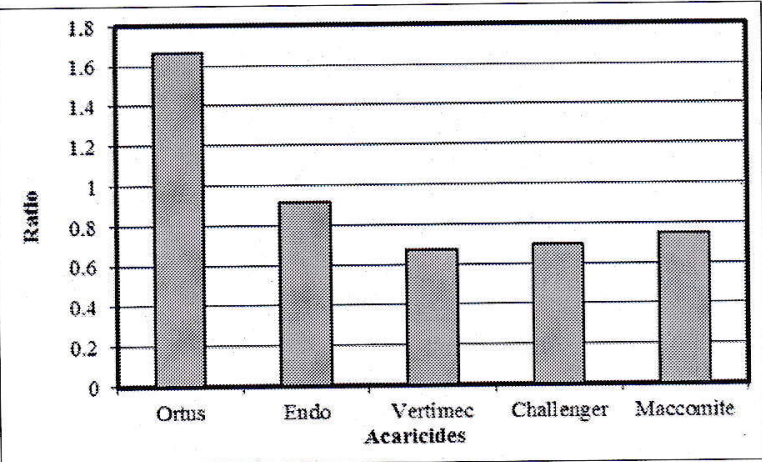

Fig. (15): Joint action of $\mathrm{H}_{3} \mathrm{PO}_{4}$ with different acaricides against $T$. urticae.

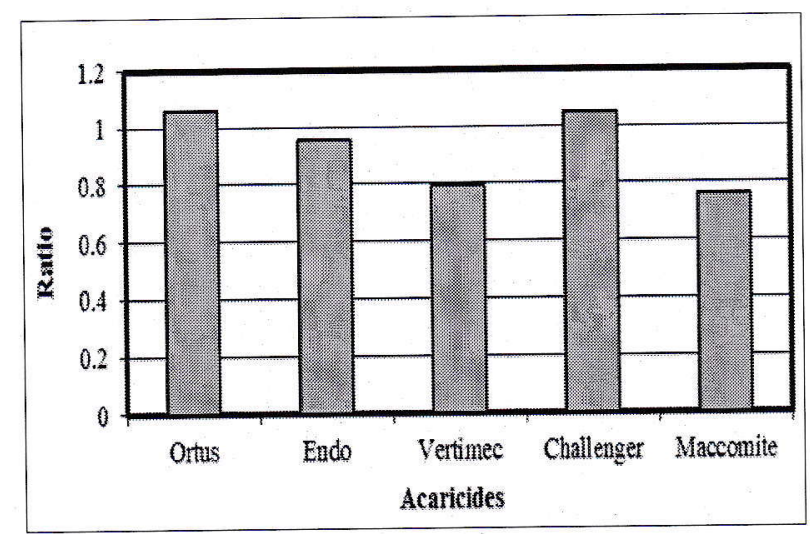

Fig. (16): Joint action of $\mathrm{CO}\left(\mathrm{NH}_{2}\right)_{2}$ with different acaricides against $T$. urticae. 
Table (1): Toxicity parameters of the tested acaricides against $T$. urticae ( 72 hours treatment)

\begin{tabular}{lccccccc}
\hline \multicolumn{1}{c}{ acaricides } & LC95 & LC $_{50}$ & rank & T.I.* & R.T.** & Recommended dose (p.p.m.) & Ratio \\
\hline Challenger $^{\circledR} 36 \%$ SC & 0.887 & 0.398 & 1 & 100 & 4654.26 & 400 & 1007.55 \\
\hline Vertimec $^{\circledR} 1.8 \%$ EC & 5.984 & 5.496 & 2 & 7.24 & 336.79 & 400 & 72.78 \\
\hline Maccomite $^{\circledR} 10 \%$ WP & 363.630 & 259.590 & 3 & 0.15 & 7.13 & 200 & 0.77 \\
\hline Ortus $^{\circledR} 5 \%$ EC & 422.800 & 329.790 & 4 & 0.12 & 5.61 & 500 & 1.51 \\
\hline Endo $^{\circledR} 50 \%$ EC & 2112.930 & 1851.000 & 5 & 0.02 & 1.00 & 1500 & 0.81 \\
\hline
\end{tabular}

* T I = Toxicity index $\quad * * \mathrm{R} \mathrm{T}=$ relative toxicity According to the $\mathrm{LC}_{50}$ values, Challenger ${ }^{\circledR} 36 \% \mathrm{SC}$ was the most toxic acaricide (TI=100) followed by Vertimec ${ }^{\circledR} 1.8 \% \mathrm{EC}(\mathrm{TI}=7.24)$, Maccomite ${ }^{\circledR} 10 \%$ WP $(\mathrm{TI}=0.15)$, Ortus $^{\circledR} 5 \%$ EC ( $\mathrm{TI}=0.12)$; while the least toxic was $\mathrm{Endo}^{\circledast 5} 5 \% \mathrm{EC}(\mathrm{TI}=0.02)$.

Table (2): Toxicity parameters (p.p.m.) of the evaluated acaricides, combined with different fertilizers, against the two spotted spider mite $T$. urticae

\begin{tabular}{|c|c|c|c|c|c|c|c|c|c|c|}
\hline \multirow{3}{*}{ Fertilizers } & \multicolumn{10}{|c|}{ Acaricides } \\
\hline & \multicolumn{2}{|c|}{ Ortus $^{\circledR}$} & \multicolumn{2}{|c|}{ Endo $^{(B)}$} & \multicolumn{2}{|c|}{ Vertimec $^{(\mathbb{B}}$} & \multicolumn{2}{|c|}{ Challenger ${ }^{\circledR}$} & \multicolumn{2}{|c|}{ Maccomite $^{\circledR}$} \\
\hline & $\mathrm{LC}_{95}$ & $\mathrm{LC}_{50}$ & $\mathrm{LC}_{95}$ & $\mathrm{LC}_{50}$ & LC 95 & $\mathrm{LC}_{50}$ & $\mathrm{LC}_{95}$ & $\mathrm{LC}_{50}$ & $\mathrm{LC}_{95}$ & $\mathrm{LC}_{50}$ \\
\hline----- & 422.87 & 329.79 & 2112.93 & 1851.00 & 5.98 & 5.49 & 0.89 & 0.39 & 363.63 & 259.59 \\
\hline $\mathrm{K}_{2} \mathrm{SO}_{4}$ & 318.26 & 231.11 & 2232.67 & 1949.00 & 7.73 & 5.06 & 0.45 & 1.16 & 432.81 & 327.08 \\
\hline $\mathrm{Fe} \mathrm{SO} 4.7 \mathrm{H}_{2} \mathrm{O}$ & 532.61 & 397.36 & 2635.72 & 2079.28 & 9.38 & 6.81 & 0.85 & 0.56 & 571.07 & 387.82 \\
\hline $\mathrm{Mg} \mathrm{SO}_{4} .7 \mathrm{H}_{2} \mathrm{O}$ & 547.53 & 402.65 & 2529.93 & 2298.14 & 10.07 & 7.88 & 0.96 & 0.58 & 569.84 & 390.16 \\
\hline $\mathrm{Zn} \mathrm{SO}_{4} .7 \mathrm{H}_{2} \mathrm{O}$ & 586.01 & 490.33 & 2335.09 & 2110.09 & 8.30 & 6.70 & 1.32 & 0.92 & 593.46 & 476.04 \\
\hline$\left(\mathrm{NH}_{4}\right)_{2} \mathrm{SO}_{4}$ & 507.66 & 426.44 & 2354.82 & 2020.27 & 7.79 & 6.82 & 0.78 & 0.60 & 536.01 & 421.62 \\
\hline $\mathrm{NH}_{4}\left(\mathrm{NO}_{3}\right)$ & 416.42 & 333.85 & 2357.83 & 2057.41 & 8.33 & 6.89 & 0.88 & 0.58 & 447.03 & 327.56 \\
\hline $\mathrm{Ca}\left(\mathrm{NO}_{3}\right)_{2}$ & 512.82 & 403.88 & 2300.88 & 2049.61 & 8.15 & 6.59 & 1.21 & 0.72 & 455.01 & 377.04 \\
\hline$\left(\mathrm{NH}_{4}\right)_{2} \mathrm{H} \mathrm{PO}_{4}$ & 505.51 & 436.79 & 2560.39 & 2370.98 & 9.22 & 7.00 & 0.95 & 0.71 & 484.55 & 348.69 \\
\hline $\mathrm{H}_{3} \mathrm{PO}_{4}$ & 251.57 & 198.00 & 2220.75 & 2025.48 & 10.58 & 8.2 & 1.01 & 0.57 & 418.98 & 347.63 \\
\hline $\mathrm{CO}\left(\mathrm{NH}_{2}\right)_{2}$ & 398.37 & 311.02 & 2282.70 & 1932.06 & 9.40 & 6.94 & 0.63 & 0.38 & 457.41 & 341.73 \\
\hline
\end{tabular}

Table (3): Antagonistic or synergistic effects of the fertilizers on the tested acaricides

\begin{tabular}{lccccc}
\hline \multirow{2}{*}{ Fertilizers } & \multicolumn{5}{c}{ Values of antagonistic or synergistic ratios } \\
\cline { 2 - 6 } Ortus $^{\circledR}$ & Endo $^{\circledR}$ & Vertimec & ${ }^{\circledR}$ & Challenger $^{\circledR}$ & Maccomite $^{\circledR}$ \\
\hline $\mathrm{K}_{2} \mathrm{SO}_{4}$ & $1.426982822 * \mathrm{~S}$ & 0.9497178 & $1.08616601 \mathrm{~S}$ & 0.34284483 & 0.79365904 \\
\hline $\mathrm{Fe} \mathrm{SO}_{4} .7 \mathrm{H}_{2} \mathrm{O}$ & 0.829952688 & 0.890212 & 0.80704846 & 0.71017857 & 0.66935692 \\
\hline $\mathrm{Mg} \mathrm{SO}_{4} .7 \mathrm{H}_{2}$ & 0.819048802 & 0.80543396 & 0.69746193 & 0.68568966 & 0.66534242 \\
\hline $\mathrm{Zn} \mathrm{SO} 4.7 \mathrm{H}_{2} \mathrm{O}$ & 0.672587849 & 0.87721377 & 0.82029851 & 0.43228261 & 0.54531132 \\
\hline$\left(\mathrm{NH}_{4}\right)_{2} \mathrm{SO}_{4}$ & 0.773356158 & 0.91621417 & 0.8058651 & 0.66283333 & 0.6156966 \\
\hline $\mathrm{NH}_{4}\left(\mathrm{NO}_{3}\right)$ & 0.98783885 & 0.89967483 & 0.79767779 & 0.68568966 & 0.79249603 \\
\hline${\mathrm{Ca}\left(\mathrm{NO}_{3}\right)_{2}}_{\left(\mathrm{NH}_{4}\right)_{2} \mathrm{H} \mathrm{PO}_{4}}^{0.816554422}$ & 0.90309864 & 0.8339909 & 0.55236111 & 0.68849459 \\
\hline $\mathrm{H}_{3} \mathrm{PO}_{4}$ & 0.755031022 & 0.78068984 & 0.78514286 & 0.56014085 & 0.74447217 \\
\hline $\mathrm{Co}\left(\mathrm{NH}_{2}\right)_{2}$ & $1.665606061 \mathrm{~S}$ & 0.91385746 & 0.6702439 & 0.6977193 & 0.74674223 \\
\hline
\end{tabular}

$* \mathrm{~S}=$ synergism.

fertilizers applied in liquid form, they found that toxicity was shown only by a mixture of ammonium nitrate and urea.

Potassium sulphate was found to have a synergistic effect on Ortus ${ }^{\circledR}$ and Vertimec ${ }^{\circledR}$; but had an antagonistic effect on Endo, Challenger ${ }^{\circledR}$ and Maccomite. Each of ferrous sulphate hepta hydrate, magnesium sulphate hepta hydrate, zinc sulphate hepta hydrate, ammonium sulphate and calcium nitrate had antagonistic effects on all the evaluated acaricides.

Ammonium sulphate and diammonium phosphate showed antagonistic effect on all examined acaricides. On the contrary, when Solla et al. (2011) evaluated the toxicity of the pyrethroid insecticide tefluthrin, and the fertilizer ammonia against the eggs of the turtle Chelydra serpentine, they mentioned that although fertilizer treatments at typical field application rates did not affect eggs, mortality was remarkably higher at three times this rate, and 100\% at higher rates. They resumed that majority of the toxicity of the mixture was not due to the insecticide; but was due to the ammonia fertilizer. Seniczak et al. (1998) confirmed that ammonium-rich air pollution, produced by a nitrogen fertilizer factory at Wloclawek (Poland), significantly decreased the arboreal and soil mites.

Phosphoric acid showed antagonistic effect on all the evaluated acaricides except Ortus. However, Parfitt et al. (2010) found that the total Oribatid mite numbers in a soil that had not received 
superphosphate fertilizer for twenty years were higher than those in the fertilized soil. Synergistic effect of phosphoric acid may refer to changing $\mathrm{pH}$ of the spraying solution. Al-Mughrabi et al. (1992) studied the chemical stability of cypermethrin at different water $\mathrm{pH}$ values; canal water $(\mathrm{pH} 8.38)$, distilled water $(\mathrm{pH} 6.20)$, phosphoric acid-treated canal water $(\mathrm{pH} 6.00)$ and propionic acid-treated canal water $(\mathrm{pH}$ 6.00). The highest percentage of hydrolysis of cypermethrin $24 \mathrm{~h}$ after treatment was found in canal water. Cypermethrin also degraded in distilled water, but at a slightly slower rate than in the canal water. Only slight losses were found to take place after 1, 4 and $24 \mathrm{hs}$ in the canal water treated with phosphoric acid or propionic acid. Because a $\mathrm{pH}$ value $>6.00$ was likely to reduce the stability of cypermethrin, they advised farmers using the King Abdallah Canal water to adjust the $\mathrm{pH}$ to 6.00 with phosphoric or propionic acid before mixing cypermethrin. Chahal et al. (2012) found that addition of micronutrients (boron or manganese) to the insecticides (fenpropathrin, lambda-cyhalothrin) changed solution $\mathrm{pH}$ dramatically. Read (1986) applied the insecticides fensulfothion and carbofuran as single sub-surface pre-planting treatments in field experiments at two locations in Prince Edward Island, one with a soil $\mathrm{pH}$ of 6.4 and the other with a soil $\mathrm{pH}$ of 5.7. Fensulfothion and carbofuran gave $>90 \%$ control of root maggots in rutabagas during wet and dry growing seasons for a period of at least 12 years. Both compounds continued to give excellent results in the more acidic soil. Synergistic effect of phosphoric acid might refer to delaying the acaricide degradation. Suett (1990) found a high significant correlation between soil $\mathrm{pH}$ and the development of accelerated degradation of the insecticide. Thus the soils in which mephosfolan was most persistent had a $\mathrm{pH}>5.6$ and the soils in which it was least persistent had a $\mathrm{pH}$ of $6 \cdot 2$ or more.

Urea showed antagonistic effect on all the examined acaricides except Ortus ${ }^{\mathbb{B}}$ and Callenger ${ }^{\mathbb{B}}$. However, Zhou et al. (1986) found that foliar sprays of Urea in water at 1:200 w/w to Pinus tabulaeformis decreased the infestation with a mite species of Oligonychus. Also, Pillai and Palaniswami (1991) found that sprays of water and urea controlled $T$. cinnabarinus (Boisduval), T. neocaledonicus Andre, Eutetranychus orientalis (Klein) and Oligonychus biharensis (Hirst) on cassava.

2.3. Comparison between the slope of $\mathrm{Ld} p$ line of the acaricide and $\mathrm{Ld} p$ line of the mixture of the acaricide and the synergistic fertilizer.

Data shown in table (4) illustrate the changes of $\mathrm{Ld} \mathrm{p}$ line slope resulting from adding the synergistic fertilizers.

Increasing the slope value of $\mathrm{Ld} \mathrm{p}$ line, as a result
Table (4) Ld p line slopes of the acaricides alone and of the acaricides mixed with the synergistic fertilizers.

\begin{tabular}{cccc}
\hline & \multicolumn{3}{c}{ Slope of Ld $\mathrm{p}$ line of } \\
\cline { 2 - 4 } & Ortus & Vertimec & Challenger \\
\hline Alone & $15.23 \pm 4.23$ & $44.6 \pm 50.83$ & $4.58 \pm 0.78$ \\
\hline$+\mathrm{K}_{2} \mathrm{SO}_{4}$ & $11.73 \pm 2.15$ & $10.21 \pm 1.35$ & - \\
\hline$+\mathrm{H}_{3} \mathrm{PO}_{4}$ & $15.82 \pm 4.56$ & & \\
\hline$+\mathrm{CO}\left(\mathrm{NH}_{2}\right)_{2}$ & $15.30 \pm 6.02$ & - & $7.57 \pm 1.10$ \\
\hline
\end{tabular}

of mixing the fertilizer with the acaricide is an indication that the examined mite homogeneous individuals showed similar susceptibility compared with the mite individuals subjected to the acaricide alone. Hence, increasing the toxicity may refer to affecting the opponent enzymes that destroys the acaricide.

Parallelism of the acaricides Ld $\mathrm{p}$ line and the mixtures (acaricide / fertilizer) Ld p line may be an indication that the mixture doesn't affect the opponent enzymes that destroys the acaricide. Hence, increasing the toxicity may refer to another reason.

On the other hand, decreasing the slope value of $\mathrm{Ld} \mathbf{p}$ line, as a result of mixing the fertilizer with the acaricide, is an indication that the examined mite individuals showed varied susceptibility compared with the mite individuals subjected to the acaricide alone.

It is favorable that farmers apply those mixtures that showed synergistic effect to enhance the potential toxicity against $T$. urticae, or to reduce the acaricides amount in the spraying solution thereupon, reducing pollution.

On the contrary, farmers have to avoid those mixtures that have proven an antagonistic effect.

\section{REFERENCES}

Ahmad, N.; Karim, K.; Masoud, A. and Fateme, A. 2009. Selectivity of three miticides to spider mite predator, Phytoseius plumifer (Acari: Phytoseiidae) under laboratory conditions. Agricultural Sci. in China, 8(3): 326-331.

Al-Mughrabi, K; Nazer, I. K. and Al-Shuraiqi, Y. T. 1992. Effect of $\mathrm{pH}$ of water from the King Abdallah Canal in Jordan on the stability of cypermethrin. Crop Protection, 11(4): 341-344.

Cao, Z.; Han, X.; Hu, C.; Chen, J.; Zhang, D. and Steinberger, Y. 2011. Changes in the abundance and structure of a soil mite (Acari) community under long-term organic and chemical fertilizer treatments. Veterinary Parasitol., 49: 131-138.

Chahal, G. S.; Jordan, D. L.; Shew, B. B.; Brandenburg, R. L.; Burton, J. D.; Danehower, D. and York, A. C. 2012. Interactions of 
agrochemicals applied to peanut; Part 2: Effects on fungicides. Crop Protection, 41: 143-149.

Finney, D. J. 1971. Probit Analysis, $3^{\text {rd }}$ Edition, Cambridge University Press, Cambridge, UK. pp 333.

Gough, N. 1990. Evaluation of miticides for the control of two-spotted mite Tetranychus urticae Koch on field roses in southern Queensland. Crop Protection, 9(2): 119-127.

Heindel, J. J.; Chapin, R. E.; Gulati, D. K.; George, J. D.; Price, Ca. J.; Marr, M. C. ; Myers, C. B.; Barnes, L. H.; Fail, P. A.; Grizzle,T. B.; $\underline{\text { Schwetz, }}$ B. A., and Yang, R. S. H. 1994. Assessment of the reproductive and developmental toxicity of pesticide/fertilizer mixtures based on confirmed pesticide contamination in California and Iowa groundwater. Fund. and Appl. Toxicol., 22(4): 605-621.

Koh, S.; Ahn, J.; Im, J.; Jung, C.; Lee, S. H. and Lee, J. 2009. Monitoring of acaricide resistance of Tetranychus urticae (Acari: Tetranychidae) from Korean apple orchards. Asia-Pacific Entomol., 12(1): 15-21.

Kwon, D. H.; Seong, G. M.; Kang, T. J. and Lee, S. H. 2010. Multiple resistance mechanisms to abamectin in the two-spotted spider mite. AsiaPacific Entomol., 13(3): 229-232.

Leeuwena, T. V.; Vontasb, J.; Tsagkarakouc, A.; Dermauwa, W. and Tirry, L. 2010. Acaricide resistance mechanisms in the two-spotted spider mite Tetranychus urticae and other important Acari. Insect Biochem. and Mol. Biol., 40(8): 563-572.

Li, Y. and Zhang, J. 1999. Agricultural diffuse pollution from fertilisers and pesticides in China. Water Sci. Technol., 39(3): 25-32.

Lu, B. Q.; Huang, X. H.; Xiao, Y.; Xhang, Y. G. and C. B. Li. 1995. Study on the control of Panonychus citri by mixed spraying of various chemical fertilizers and surface-active agents. China Citrus, 24(2): 35-37.

Oliberius, J. and Veverka, K. 1985. Insecticidal and acaricidal toxicity of nitrogen fertilizers applied in liquid form. Sbornik-UVTIZ, Ochrana Rostlin, 21(4): 299-305.

Palevsky, E.; Ucko, O.; Peles, S.; Yablonski, S. and Gerson, U. 2004. Evaluation of control measures for Oligonychus afrasiaticus infesting date palm cultivars in the Southern Arava Valley of Israel. Crop Protection, 23(5): 387-392.

Parfitt, R. L.; Yeates, G. W.; Ross, D. J.; Schon, N. L.; Mackay, A. D. and Wardle, D. A. 2010. Effect of fertilizer, herbicide and grazing management of pastures on plant and soil communities. Appl. Soil Ecol., 45(3): 175-186.

Pillai, K. S. and Palaniswami, M. S. 1991. Integrated approach for the management of spidermite complex on cassava. Root Crops, 17(1): 44-49.

Read, D. C. 1986. Influence of weather conditions and microorganisms on persistence of insecticides to control root maggots (Diptera: Anthomyiidae) in rutabagas. Agric., Ecosys. Environ., 16(3-4): 165-173.

Seniczak. S.; Dabrowski, J.; Klimek, A. and Kaczmarek, S. 1998. Effects of air pollution produced by a nitrogen fertilizer factory on the mites (Acari) associated with young Scots pine forests in Poland. Appl. Soil Ecol., 9(1-3): 453458.

Solla, S. R. d.; Martin, P. A. and Mikoda, P. 2011.Toxicity of pesticide and fertilizer mixtures simulating corn production to eggs of snapping turtles (Chelydra serpentina). Sci. of Total Environ., 409(20): 4306-4311.

Suett, D. L. and Jukes, A. A. 1990. Some factors influencing the accelerated degradation of mephosfolan in soils. Crop Protection, 9(1): 4451.

Sun, Y.P. 1950. Toxicity index: an improved method of comparing the relative toxicity of insecticides. J. Econ. Entomol.,43: 45-53.

Veverka, K and Oliberius, J. 1986. Pesticidal effect of liquid fertilizers. Agrochemia, 26(11): 327-331.

Wan, N.; Ji, X.; Jiang, J.; Qiao, H. and Huang, K. 2013. A methodological approach to assess the combined reduction of chemical pesticides and chemical fertilizers for low-carbon agriculture. Ecological Indicators, 28: 344-352.

Zhou, Z. Y.; Su, X. L. and Zhang, Z. S. 1986. Relationship between tree nutrition and insect pests: the effect on resistance to insects after nitrogen fertilizer application to Pinus tabulaeformis. Acta Entomologica Sinica, 29(3): 283-290. 